\title{
The Burgher Family
}

The family, the most basic and enduring form of community, has always functioned as part of a wider social system and reflected the changes this system underwent over time. The size, shape and meaning of the family and the bonds between its members were influenced by an ongoing process of social, economic and cultural change. In the Middle Ages, the Church played a modernizing role in this respect: Christianity's adoption of a new, relatively coherent set of moral and formal concepts, values and principles greatly impacted all aspects of social life, giving rise to what is commonly termed Latin civilization. ${ }^{1}$ Among the spheres in which the Church made a strong effort to exert greater control was the family and familial and marital relations. Yet, paradoxically, through its efforts to enshrine and sanctify the affective dimensions of the institution of marriage, the Church contributed greatly to a lessening of the importance of blood relations, and thus to the dissolution of the traditional family model, based on kinship. ${ }^{2}$ It did so, on the one hand, by rejecting the means conventionally used to maintain strong, cohesive family kinship bonds, including adoption, cohabitation, inbreeding and the marrying of widows of deceased family members. ${ }^{3}$ Meanwhile, one the other, it cherished and sanctified the affective and consensual aspect of marriage, ${ }^{4}$ supporting both the right of women to inheritances and of every man to dispose of his property

1 Regardless of how ambiguous, questionable and difficult it would be to define the term 'Latin civilisation,' the same problem exists with the analogous concepts of the 'Western world' and 'Western civilisation'; cf. Berman Harold Joseph, Law and Revolution. The Formation of the Western Legal Tradition (Cambridge-London: Harvard University Press, 1983), 1-14; Pierre Chaunu, Le temps des Réformes: histoire religieuse et système de civilisation: la crise de la chrétienté: l'éclatement, 1250-1550 (Paris: Fayard, 1975); Norbert Elias, Przemiany obyczajów, 7-16.

2 Jack Goody, The Development of the Family and Marriage in Europe, 103-156.

3 The Church gradually extended restrictions not only to marriages between blood relatives, but also between non-related family members and 'spiritual relatives' - godfathers and godmothers. In the sixth century, marriages were prohibited to the third degree of consanguinity, then in the eleventh century the ban was extended to the seventh degree; ibidem, 55-59, 73, 144.

4 Which contradicted the primary role of obtaining the family's permission to marry and undermined the authority of the head of the family.

(C) JAKUB WYSMUŁEK, 2021 | DOI:10.1163/9789004461444_005

This is an open access chapter distributed under the terms of the CC BY-NC-ND 4.0 license. 
by means of a will. 5 These actions by the Church were motivated primarily by theological and moral concerns, but they were also meant to weaken the ties between individuals and their kin and to incorporate them into a new, universal religious community. One important aspect of this phenomenon was the substantial benefits the Church derived from espousing a model of ownership based on private, rather than communal or familial, ownership of goods. The right to freely dispose of one's estate (initially roughly one-third of it) ${ }^{6}$ was promoted so that people could 'piously' donate their property to the Church, thus designating, as Saint Augustine observed, "Christ as their heir."

In Polish lands, such pivotal changes began to be introduced only in the thirteenth century, i.e. after the Church's organizational structure and a new legal system based on a Western model had become well-established. Initially, new laws applied only to foreign settlers who moved to Polish lands, but they soon began to regulate the functioning of society at large, which "moved from the notion of community or kin ownership, in which women basically had no rights, to a private, family-controlled system, in which women, unmarried, married and widowed, were given the right to dispose of their private and inherited property" 8 Influenced by these new cultural trends and encouraged by the Church, women began for the first time to finance religious institutions on a large scale; initially these patrons were primarily princesses and duchesses, but women from the noble elite soon followed suit. ${ }^{9}$ In the fourteenth century, rich members of the patriciate, both women and men, from the rapidly growing and prospering cities of the Kingdom of Poland, also began to make generous donations to finance new religious institutions. Although exceptional for its time, the earliest surviving Krakow will, made by an affluent burgher woman named Sulisława (Sulislava civis Cracoviae) in 1303, provides a perfect example of this process. ${ }^{10}$ In the will Sulisława, who shared some sort of a connection

5 Michael M. Sheehan, The Will in Medieval England, 234-241; Jack Goody, The Development, 122.

6 Cf. Chapter 1.

7 Karol Koranyi, Podstawy średniowiecznego prawa spadkowego, "Pamiętnik HistorycznoPrawny" 9, 1930, no. 2, 196; cf. Chapter 1.

8 Jack Wiesiołowski, "Zmiany społecznej pozycji kobiety w średniowiecznej Polsce," in Kobieta w kulturze średniowiecznej Europy. Prace ofiarowane Profesor Alicji KartowskiejKamzowej, ed. Antoni Gąsiorowski (Poznan: Wydawnictwo Poznańskiego Towarzystwa Przyjaciół Nauk, 1995), 42.

9 E.g. St. Hedwig of Silesia, St. Kinga of Poland, blessed Yolanda and blessed Salomea; cf. ibidem, 42-43. KDM K, vol. 3, no. 368, 493-494. 
with Albert, the vogt of Krakow, ${ }^{11}$ made very generous pious bequests to the Dominican and Franciscan monasteries and to St. Mary's Basilica in Krakow.

In the articles of Magdeburg Law (the Weichbild and Sachsenspiegel), the family is characterised as a traditional, strong feudal institution. ${ }^{12}$ Marriage by contrast is portrayed as a frail institution, a necessary transitional stage, in contrast to the proven strength and permanence of family bonds based on kinship and blood relations. Unlike with the 'Chełmno law,'13 under Magdeburg Law there was a division of property between the spouses. After the death of one spouse, the couple's common property was divided accordingly between the families of the husband and the wife. Such a solution had serious consequences for the widow, who from the couple's estate only had rights to her dower and - if the late husband made the necessary arrangements - some form of annuity (vita provisio). ${ }^{14}$ The remaining part of the property was given to the husband's relatives, according to their 'right of expectation. ${ }^{15}$ Likewise, after the death of the widow, her dower (as compensation for her dowry) and vita provisio were not considered her personal estate, but were instead inherited by her late husband's family. ${ }^{16}$ Only a portion of her movable property (in Latin suppellectilia, in German gerade; known also as wyprawa under Polish customary law) was inherited by her daughter or, if the widow had no

He was made both the beneficiary of part of the provisions and their executor; ibidem

This was affected by, among other things, the nature of the Sachsenspiegel, which regulated land law (Landrecht) and fief law (Lehnrecht). Research has shown that initially the Sachsenspiegel had greater significance in the creation of the first Polish city law codes than Magdeburg Ius civile; Zygfryd Rymaszewski, Eacińskie teksty Landrechtu Zwierciadta Saskiego w Polsce: versio Vratislaviensis, versio Sandomiriensis, taski (Wrocław: Zakłas Narodowy Im. Ossolińskich, 1975), 6.

Prawo starochetmińskie 1584 (1394), ed. Witold Maisel, Zbigniew Zdrójkowski, trans. Andrzej Bzdęga, Alicja Gaca (Toruń: Uniwersytet Mikołaja Kopernika, 1985).

"[...] si aliquis ducit uxorem et si vir de hac luce decesserit, uxor nihil habet in suis bonis nisi dederit sibi pro dotalicio, aut vita provisione pro eius vita in iudicio bannito"; Jan Łaski, Commune Incliti Poloniae, Libri duo, part 1, 178.

15 In the mid-sixteenth century, Bartłomiej Groicki recounted the rules of inheritance in Magdeburg Law: "There are four degrees to the inheritance of a deceased person who had not made a will. The first degree is the children. The second, the parents. The third degree includes other individuals mentioned above. The fourth degree is a husband and wife, who inherit from one another when there are no parents, no children, no brothers, no sisters or others down or across the family line. Finally, if there are no individuals belonging to the categories described above, then the inheritance and possessions of the deceased belongs to the royal treasury"; idem, Porzadek sadów i spraw miejskich prawa majdeburskiego w Koronie Polskiej (Warszawa: Wydawnictwo Prawnicze, 1953), 181.

16 "Nulla mulier potest vite provisione nec dotalicium hereditarie observare et cum de hac luce decedit ad heredes revertitur sui mariti"; Jan Łaski, Commune Incliti Poloniae, Libri duo, part 1, 178 . 
daughters, by her closest female relative. ${ }^{17}$ The unwritten logic behind these provisions was that after the husband's death, the widow should return with her dower (equivalent to her dowry) and gerade to her own family. Male relatives of the late husband took custody of the children. Once all these arrangements were finalized, the marriage was considered dissolved.

Apart from the conservative social system enshrined by Magdeburg Law and the modernizing influences of the Church, a third force that influenced the shape of family relations in late-medieval cities was the changing nature of work and the conditions of everyday life. ${ }^{18}$ Cities were populated mostly by first-generation or second-generation immigrants, and the freedom to inherit property and dispose of one's estate allowed to some of them to accumulate capital. In view of these aspects of urban life, the practices of medieval municipal courts, so-called living law, ${ }^{\prime 19}$ introduced new measures which undermined the severe and archaic system of kin ownership and separate property. Wills played an important role in this process as 'tools of power' because they made individuals active subjects of family relations, also in relation to the law. Wills allowed individuals to shape desirable family relationships, for example to exclude unwanted relatives from inheritance or to include in the group of heirs persons not related to them by ties of blood. This 'power' significantly influenced the evolution of the family institution in the city and the formation of its separate models within the city elite and middle classes of the burgher's communitas.

\section{$2 \quad$ New Forms of Bequests for Wives}

Despite the existence of generally uniform and unchangeable regulations limiting the widow's right to inheritance, fourteenth-century and fifteenth-century

17 Urszula Sowina, "Wdowy i sieroty w świetle prawa w miastach korony w późnym średniowieczu i wczesnej nowożytności," in Od narodzin do wieku dojrzatego. Dzieci i mtodzież w Polsce, part. 1: Od średniowiecza do wiekuXVIII, ed. Maria Dąbrowska, Andrzej Klonder (Warszawa: Instytut Archeologii i Etnologii Polskiej Akademii Nauk, 2002), 18-19. Aside from the gradual evolution of urban life in Krakow, another significant factor was the adoption of social and legal remedies already present in other developed cities in the region. The concept of living law was adopted by Leopold Pospísil, an anthropologist of the law, from the work of the nineteenth-century sociologist Eugene Ehrlich: "The living law is not the part of the content of the document that the courts recognize as binding when they decide a legal controversy, but only that part which the parties actually observe in life"; Leopold Pospísil, The Ethnology of Law (New Haven, Conn.: Human Relations Area Files, 1978), 61. 
century testators were in fact relatively free to plan for the widow's future and decide what part of the estate she should inherit. Many testators exercised this right to decide about the widow's future - some husbands clearly indicated what part of their movable and immovable property should be used to secure the widow's dower and what household goods should constitute her gerade. ${ }^{20}$ Others, in turn, chose to give the wife one-third of the entire estate in exchange for her dower ${ }^{21}$ (such as the alderman John Bozemecz in 1394), ${ }^{22}$ half of the entire estate (just like the burghers Lawrence, who lived at St. Anna Street, and Theodoric Doring) ${ }^{23}$ or even the entire estate (because there were no other heirs, after the death of the widow, the estate was to be donated to opera pietatis). ${ }^{24}$ While final bequests contained in fifteenth-century wills vary greatly, reflecting the testator's specific family, financial and social situation, we can distinguish three basic models in them for securing a widow's right to inheritance. In the first, the widow receives her gerade and a dower secured by her late husband's estate, the sum of which was fixed in advance (and often supplemented by an additional sum of money - a so-called przywianek in Old Polish). The late husband's children or relatives were obligated to pay the widow what she had been promised, and until they did so, she had the right to make use of her husband's property. One such bequest was made by the shoemaker John Panzira in 1458. His wife Catherine was granted the right to live in their wooden house at St. John Street and retain possession of other movable and immovable goods until she received a dower of 30 grivna. ${ }^{25}$ The painter (pictor) Martin made a similar bequest in 1463 . He bequeathed to his wife Catherine a dower of 50 grivna, supplemented by an additional 20 grivna, secured by his movable and immovable property. Catherine was given the right to make use of her late husband's estate until she was paid the dower owed to her by those appointed as executors of the testament. ${ }^{26}$ Apart from the dower to which the wife was entitled by law, some testators also bequeathed their

20 SCAB., no. 2070 (1395).

21 The principle of a $1 / 3$ free part of one's possessions had been known in church law since the early Middle Ages, and this is also the source of this principle in Poland.; cf. Berman Harold Joseph, Law and Revolution, 230-231; Karol Koranyi, Podstawy średniowiecznego prawa spadkowego, 194-195; Urszula Sowina, "Testamenty mieszczan krakowskich o przekazywaniu majątku w późnym średniowieczu i we wczesnej nowożytności," in Sociální svět středověkého města, ed. Martin Nodl (Praha: Filosofia, 20o6), 177. SCAB., no. 1914.

23 SCAB., no. 1894, 1913.

24 SCAB., no. 1774 (1393), 2069 (1395).

25 LT, fol. 5 .

26 LT, fol. 80. 
wives a share of the estate, often one equal in size to that inherited by the children (i.e. the wife was treated on equal terms with the children as an heir). For example, in 1466 Andrew Zyra, a Krakow merchant, bequeathed to his wife a dower of 100 grivna, and also gave her the equivalent of their daughter's inheritance, i.e. half of all remaining property. Many testators did not specify the amount of the dower or gerade, but simply bequeathed a specific real estate property or share of the estate to the widow in lieu of a dower and other goods she had the right to receive. The councillor Hippolyte Spilberger made such a bequest in his will in $1469 .{ }^{27}$

The spouses also provided for one another financially by means of so-called 'subsistence bequests,' i.e. agreements between a husband and wife that provided for the mutual inheritance of their property. ${ }^{28}$ In the event of the death of one of the spouses, the surviving spouse had the right to inherit the entire estate. ${ }^{29}$ Such contracts clearly stated that all other relatives were disinherited. ${ }^{30}$ This not only secured the widow's future financially, it also provided the husband with the assurance that if his wife died, her family would not have the right to her property, which would instead remain with him. Such bequests first began to appear in Krakow's municipal books in the 1350s. They quickly became very popular, as evidenced by the number of similar bequests found in the sources. It appears that in the mid-fourteenth century, Krakow's burghers were given the right to freely dispose of all of their property and to bequeath it to their surviving spouse, at least for the remainder of their lifetime, turning it into a form of annuity, which was permitted under municipal law. These formal changes in the law are evidence of the profound changes burgher family relations were undergoing at that time.

\section{3}

\section{The Situation of the Widow}

Changes that were gradually introduced into municipal law and the growing popularity of the institution of the will enabled Krakow's burghers to make

\footnotetext{
$27 \quad$ LT, fol. 95 .

28 Urszula Sowina, Wdowy i sieroty, 19.

29 E.g. "Tilusz cerdo resignavit Margarethe uxori sue omnia bona mobilia et immobilia post mortem, si decesserit absque liberis, et ipsa domina Margaretha econverso resignavit dicto Tilusszio suppellectile et omnia alia bona, que habet”; SCAB., no. 279 (1368).

30 "Paszko Skalka omnia bona sua, que habet aut habiturus est quomodolibet in futurum, Anne uxori sue post mortem suam dedit et ipsa sibi econverso alia littera; reservat maritus dominium et ambo excludunt amicos"; SCAB., no. 2185 .
} 
bequests and other plans concerning their property while they were still alive in order to secure the material well-being of their families. At the same time, due to the provisions of municipal law that discriminated against the widow, most testators wished to shield the widow from poverty and from inheritance disputes with the family of the late husband. ${ }^{31}$ Naturally, testators used different methods to this end, depending on their familial and financial situation.

A number of wills from the 139os, whose form (and probably function) was similar to that of pre-nuptial marriage contracts, provide insight into the situation of the widow. It appears that in at least some cases such wills were drafted shortly after the testator married his first or second wife. ${ }^{32}$ This is evidenced by the form of the bequest, which includes a detailed description of the wife's future living situation after the death of the husband and her inheritance rights, as well as annotations concerning the inheritance rights of any children they might have. For example, the councillor Nicholas Strelicz left his entire estate to his wife. However, if the couple had any children, they would inherit part of the estate. ${ }^{33}$ Similarly, Peter Puczk specified in his will the amount of his wife's dower - she was to receive 81 grivna, but only if their marriage was childless. "However, should God give [Peter Puczk] an heir," the widow was to receive a smaller inheritance. ${ }^{34}$ In two bequests, testators explicitly stated that they wished to protect the right to inheritance of the second wife, specifying that the estate should be divided among the second wife, any children from the second marriage, and the children from the first marriage. ${ }^{35}$

Instructions regarding the material well-being of the wife varied. Husbands took into consideration whether the wife would decide to remain a widow, which usually meant looking after the house, raising children and cherishing the memory of the late husband, or whether she would remarry. In other words, husbands based their decisions on whether the wife would remain in his family or remarry and thus enter the family of the new husband. ${ }^{36}$ Although we should not underestimate the emotions involved in testators' decisions, i.e. their wish for the wife to remain faithful and dedicated to the memory of the late husband, it seems that such bequests were made predominantly

$3^{1} \quad$ Urszula Sowina, Wdowy i sieroty, 19.

$32 \quad$ SCAB., no. 1645 (1393), 1654 (1393), 1816 (1393), 1894 (1394), 2042 (1394), 2070 (1395), 2093 (1395), 2210 (1395), 2354 (1396). Probably also: cons. 428, fol. 231 (1426); cons. 429, fol. 372 (1466)

"[...] si vero pueros ex se procreaverint"; sCAB., no. 1645; cf. Jacek Laberschek, Mikotaj Strzelicz, in PSB, vol. 45 (Warszawa-Krakow: Polska Akademia Nauk, Polska Akademia Umiejętności, 2007), 16-17.

36 Brigitte Klosterberg, Zur Ehre Gottes und zum Wohl der Familie, 208. 
because husbands feared that the wife would squander the inheritance once she remarried. Testators tried to protect their children against such an unfortunate event in various ways. They subjected their wives to the control of the appointed guardians (tutores), bequeathed specific parts of the estate to their children, and encouraged their wives to remain widows. For example, in 139o, in the presence of his wife Catherine and before the municipal bench court, Stanisław Grudner ${ }^{37}$ made a bequest to Catherine of 40 grivna and half of their household items, which constituted her due dower. ${ }^{38}$ Grudner further stated in the contract that if Catherine remained a widow, then she, together with two guardians appointed by Grudner, would have the right to raise any children resulting from the marriage and administer their inheritance until any son they might have turned 24 years old or any daughter married; the children would then be given their separate shares of the estate. ${ }^{39}$ If one of the children died, their inheritance should be equally divided between Catherine and the surviving children. Once all the children had received their shares of the estate, the widow would receive 40 grivna as her dower. Thus, while the wife was only entitled to her dower, the amount of which had been determined at the betrothal, as a widow she became the acting head of household, with her late husband's entire estate at her disposal.

A similar contract was made in 1395 by the alderman John Dobschicz. He stated that "if his wife decides to remain a widow, she should take custody of the children and maintain control over the entire estate. ${ }^{40}$ However, if she remarries, she should be given 250 grivna as her dower, her gerade and everything else that she is entitled to." ${ }^{\text {11 }}$ Thus, if Dobschicz's wife remained a widow, and if their marriage was childless, she would receive 250 grivna, one-third of the house, and the household items that constituted her gerade. The wife was to manage her late husband's entire estate until her death. Afterwards, it was to be divided equally among the relatives of the late husband, a hospital and charitable bequests.

37 He was probably related to the alderman Nicholas Grudner, who held this function in 1385, 1392-1393; KDM K, vol. 3, 52-53.

38 "[...] eidem domine XL mrc. et medietatem suorum suppellectilium, videlicet rade dictorum, racione dothalicii et pro omnibus, que ipsam concernere possent"; SCAB., no. 1267 .

39 "[...] si vero vidua permanserit, extunc eadem domina cum infrascriptis tutoribus eorum pueris debent preesse et cum eorum bonis dictos pueros apud se retinere, nec aliquem dictorum puerorum, si masculus fuerit, a se separare, donec ad etatem XXIIII annorum pervenerit, si femina, non prius, nisi marito copuletur"; ibidem.

$40 \quad$ "[...] ap se witve blebe, so sal se mit vormunden seyn vnd roten vor ir kinder, vnde behalde der goben hirschaft, dy weyl ich lebe"; cf. scAB., no. 2093.

41 " [...] ap dy vorgenante Katherin eynen man neme, zo zal man ir geben II $1 / 2 \mathrm{C} \mathrm{mrg}$. czu tun vnd czu lassen vor morgengabe vnd vor alle ding an ir gerade, dy ir von rechte geborit”; cf. ibidem. 
However, husbands did not always trust their wives (and future widows) unconditionally. In 1393, John Ederer, an alderman and later member of the Krakow municipal council, authenticated his will, which he had made on a sheet of paper, before the municipal bench court. ${ }^{42}$ Like Grudner and Dobschicz, Ederer stated that if his wife remained a widow, she (along with their children) would remain "the mistress of the entire estate until her death."43 However, the appointed testamentary guardians were to audit the family's finances each year. If they were in good order, the widow would continue to manage the estate. If the opposite was true, the guardians were to step in, take control of the estate, and pay an allowance to the widow and the children to satisfy all their needs. ${ }^{44}$

Childless testators often stated in their wills that their wives should be given their entire estate, or parts of it, in the form of a jointure. They specified that the widow would administer her late husband's estate until her death, but the estate would eventually be inherited by the relatives of the late husband or religious institutions. For example, in 1395, John (Hanco) Czartke bequeathed his house at Shoemaker's Street to his wife, instructing the appointed testamentary guardians to sell it after her death and donate the money to selected religious institutions. ${ }^{45}$ The affluent burgher John Reichil made a similar bequest in 1442. He left his entire estate to his wife, but after her death the appointed testamentary guardians were to donate everything to fund opera pietatis. ${ }^{46}$

42 "[...] eyn czedilpapir, dorin her syn testament vnd lecztin willin yn geschrebin hatte"; SCAB., no 1676; cf. Józef Mitkowski, Jan Ederer, in PSB, vol. 6 (Krakow: Polska Akademia Nauk, Polska Akademia Umiejętności, 1948), 201-202.

"[...] sy mynes guttis eyne vrawe bleybin mit sampt mynem kinde bis an ir ende"; SCAB., no. 1676 .

44 " [...] alzo daz sy rechenunge tue alle jar den vormunden von dem gutte; is das sy das gut bessert, so sullin is ir dy vormunde lossin, wo sy ys nicht enbessirte, so sullen is dy vormunden nemen czu en vnde sullen de mete des bestin nemen vnd sullin muttir vnd kinde ere notdorf douon gebin"; ibidem.

45 "Hanco Czartke gibt noch seyme tode seyn hus gelegin of der Zewgassen, dorynne her wonet, frawen Katherin seyner elichin husfrawen, das se dorynne sal wonen vnd seyn genissen, dy weil se lebit, hengelegt allirley hindernis seyner frunde, vnd noch der frawen tode sullin dy nochgeschrebin vormunden das hus vorkowfen vnde sullin das noch geschrebin gelt geben personen vnde steten, den is beschrebin stet"; SCAB., no. 2069.

46 "[...] alle seyn gut beweglich und unbeweglich das her hot adir ummir haben wirt Dorothee seyner elichen hausfrawen vorrecht und ofgegeben noch seyme tode czu habin mit woller macht czu tuen und czu lossen. Sonder des haws of der Spitler gasse hot her ir gegeben czu irem lebin, und noch irem tode sal is vorkowft werden und das gelt do vor komen in dy werck der barmherczikeyt, wo und wy sy das befelen wirtin irem testament noch irem besten vornemen, und noch undirweysunge irbarrleute"; SCAB. 6, fol. 256 . 
Testators who had children, especially from a first marriage, sought to ensure that the widow would have a place to live and that the stepchildren would take care of her. The courts generally ruled that the widow could "remain in the estate of the husband" until she received her dower. Once a dotalicium, or dower, was paid, however, the widow was forced to leave the house. In order to prevent such a situation, some wills clearly stated that the widow was to be given a room or chamber in the house of the late husband. The Krakovian patrician Thob Johan made such a bequest in his 1443 will. He stated that if his wife remained a widow, she would receive 700 grivna (constituting her dower and half of the inheritance after the death of their son) and have the right to live in their house until her death. She was to have access to the fireplace and given all that she required.$^{47}$ The Krakow alderman John Czarny left even more detailed instructions to his children:

In addition, my wife is allowed to live in my house until her death. She is to be given the sunny room which overlooks the meat market and one free table in the dining room to sit at that is near the stove and close to the. Moreover, she should also be given all that she requires. ${ }^{48}$

The widow was a vulnerable target for relatives of the late husband who wished to come into possession of the estate. Her situation was especially difficult when she was childless, because she could not dispose of the estate on behalf of non-adult children. Thus, only a will could give her the right to live in the family house and inherit marital property. Of course, even when such a will existed, relatives still actively sought to have their right to inheritance recognized by the court, invoking their rights as family members. Arbitrators ruled on such cases taking into account not only the provisions of the law, but also (and seemingly above all) local customs, a sense of social justice, and a need to avoid lasting conflicts in the local community. For example, we learn from municipal books that in 1462 John Moler, brother of the late Wojtek Moler, made a settlement with Dorothy, the wife of the deceased. ${ }^{49}$ The appointed arbitrators, among whom there were two state officials, called undirwoiwod, ${ }^{50}$ two councillors, and two aldermen, made considerable changes to Moler's will. Instead of the 100 florins her late husband had promised her, the widow

\footnotetext{
$47 \quad$ LT, fol. 7-8.

48 SCAB. 8 , fol. 223 .

49 CONS. 429 , fol. 297.

$5^{\circ}$ This was probably the position of the deputy voivode (Latin vicepalatinus) - an official responsible primarily for the supervision of prices, measures and weights.
} 
was to be paid 8 o florins as her dower. ${ }^{51}$ The remaining 20 florins were to be given to John. Valuable supellectilia, such as silver cups and spoons, were to be divided evenly between John and the widow. Half of the house, which the widow had received "for her use" (czu gebrauchen of das), was to be given to John in exchange for an annual rent. In addition, John was to be given a table, sheets and a silver belt with a cord as a hergewet (the hereditary property due to a man). The meat found in the house was also to be divided in half. So, while they respected some of Wojtek Moler's testamentary bequests (for example, a pious bequest of a silver chalice to St. Bernard's Church), in general, the arbitrators adapted them to the traditional inheritance rules of relatives of the late husband and the principle of separate property. Similarly, we learn from a record made in 1432 that Nicholas, a relative of the late Wojtek and a silk embroiderer (zeydinhafter), sued Catherine, the widow of Wojtek, demanding the house and hergewet (arma bellica paramenta vulgariter hergewete). In this case, however, the court decided that the widow was to receive the compensation of her dower first; only then could the property be divided. ${ }^{52}$

A woman's private property consisted of her dower and everything she had earned while working alongside her husband. In addition, she could also receive a large inheritance after the death of her parents, which often greatly increased her importance in the family and society. The analysed wills show that women often had at their disposal property they inherited from their parents. For example, in 1405, the widow Dorothy Pauswanginne, in disposing of her goods, made bequests to her family worth 160 grivna. In addition, she also stated in her will that she possessed a dower of 200 grivna, 30 grivna in cash, a generous inheritance from her father, and her gerade. ${ }^{53}$ Likewise, in her 1461 will, Ursula Grunwaldinne left her husband a house at Shoemaker's Street, which, as she testified, she had inherited from her parents. ${ }^{54}$ We can assume that a will or bequest to the other spouse was meant to settle accounts between a husband and wife after the wife had received an inheritance from her parents. For example, in 1451, the armorer (lorifex) Thomas and his wife Catherine appeared before the court to legalize a gift inter vivos of all their

$5^{1} \quad$ This will has not survived to the present day, but its dispositions are mentioned in detail in the analyzed citation.

"Sententiatum est Katherine Jostynne relicte Woitkonis Zeydinhafter quod exquo Micolai intromisit se de domo ipsius Woitkonis Zeydenhafter mariti sui et postulat consequenter eciam bellica paramenta vulgariter hergewete, et relicta ipsius defuncti illa habet in sua tenuta wulgariter gewer, tunc ipsa non debet paramenta illa bellica que apud se tenet, alicui dare, nisi facta prius sibi satiffaccione de dote sua de Jure"; sсAB. 6, fol. 32.

53 CONS. 427, fol. 241.

54 LT, fol. 70 . 
armamentalia and paraphernalia. The remaining part of the estate was to be inherited by the other spouse. After making this bequest, Catherine decided to sell the one-fourth of the house at Grodzka Street that constituted her inheritance. ${ }^{55}$ Here, the mutual bequest was meant to secure Catherine's marriage property share after the sale of her inherited property. A similar contract was made in 1451 between Hedwig and her husband Konrad Lang (Cuncze Lang), a councillor ${ }^{56}$ Hedwig gave Konrad the rights to all her goods, including those she already owned, those she was to inherit from her father, and those she was to inherit from her grandfather Peter Graser's will. ${ }^{57}$ In exchange, Konrad made a bequest to his wife of 400 grivna (as her dower), to be paid out of his estate. In this case, the dower acted as a security for both the wife's dowry and her inheritance.

If a burgher failed to secure his wife's future by means of a will or a mutual bequest, after his death, as mentioned above, a widow who did not have custody of minor children or a widow who decided to remarry had no right to the estate and had to leave the family house. ${ }^{58}$ As a result, many widows did not remarry. They chose to honour the will of the husband, manage the estate, and take care of the children. In any case, they chose not to put their material and social position at risk. In view of the fact that women married at an earlier age than men, many widows must have survived their husbands in the medieval city. ${ }^{59}$ It thus appears that the wealthiest burghers actively sought to discourage their wives from remarrying. For example, in 1462, the councillor Jarosz Szarlej increased the dower of his wife Margaret so that "she would take care of their children." ${ }^{60}$ Poorer burghers, in contrast, realized that after their death, a new marriage could save their wives from poverty. For that reason, in 1458, the shoemaker John Panzira bequeathed 30 grivna to his wife Catherine, which constituted her dower, and allowed her to "benefit from shoemaking" (uti artem sutoriam) until she found a new husband. ${ }^{61}$

Testamentary bequests and bequests of similar nature, such as mutual bequests or dower bequests, were meant to effectively undermine the

\footnotetext{
55 SCAB. 7 , fol. 16 o.

$5^{6} \quad$ Marcin Starzyński, Krakowska rada miejska w średniowieczu, 278.

57 SCAB. 7 , fol. 165 .

58 Brigitte Klosterberg, Zur Ehre Gottes und zum Wohl der Familie, 209.

59 Jack Goody, The Development, 64.

6o "[...] durch des wille das sy dastir fleissiger sal meyne kynder auswartin und dyneryn"; LT, fol. 73 .

61 "Item dedit bona voluntate dicte uxori sue quod ipsa debet uti artem Sutoriam et frui Scampnum artes eiusdem et tali condicione scmapnum habere debet donec maritum alium non duxerit"; LT, fol. 5 o.
} 
traditional system of property division. They helped maintain the integrity of the nuclear family, at the expense of other kin, even after the death of one of the spouses. The spouses inherited not only the property they had earned together, but also their respective private inheritances. Such bequests demonstrate that a new form of the institution of marriage had been strengthened it was now not only a financial or social union, but also an emotional one, as well. As official documents, fourteenth-century and fifteenth-century wills rarely contained any personal or emotional remarks. However, the fact that the wife often inherited the entire estate at the expense of other relatives speaks for itself. Still, some emotional remarks in wills have survived. For example, in 1438, John Unger (a Hungarian) made a bequest of all his movable and immovable property to his wife, arguing that "he and his wife had earned everything together." ${ }^{\prime 2}$ The example of the salt merchant (sallicida) Michael Godzek is even more telling. In 1494, Godzek left his entire estate to his wife Dorothy, disinheriting all his relatives. He stated that "Dorothy worked with him constantly and faithfully. She nourished, warmed and served him with her guidance and work." 63 In view of formal requirements, such words of gratitude for the hard work shared and property accumulated together could be read as a declaration of love. Such statements were even more common in sixteenth-century and seventeenth-century wills. ${ }^{64}$

\section{4}

\section{Children}

Most married couples plan to have children and share the hope that raising them will give their future lives special meaning. In the Middle Ages, children were seen as 'guardians of immortality' in a double sense, as they were expected both to pray for their parents' salvation in heaven and preserve their memory on earth. ${ }^{65}$ If a testator had children, it was they who would eventually inherit the estate, even if the wife was originally named in the will as the main beneficiary.

62 "[...] dixit quidem testator quod ipse eadem bona relicta cum eadem consorte sua laboribus acquisivisset"; LT, fol. $3^{-4}$.

63 "In primis dixit quod uxor sua legitima Dorothea fideliter, semper cum eo egit et sua providencia et laboribus eum nutrivisset, foveret et servaret"; LT, fol. 154.

64 "Such remarks are more frequent in the wills of men than in the wills of women, and they usually display such attributes of marital harmony as: love, commitment, fidelity, mutual support in their work and the upbringing of children, care in old age and illness"; Andrzej Karpiński, Kobieta w mieście polskim w drugiej połowie XVI i w XVII wieku (Warszawa: Instytut historii PAN, 1995), 197.

65 Brigitte Klosterberg, Zur Ehre Gottes und zum Wohl der Familie, 212. 
Although wills often mentioned children, as source materials they do not provide a sound basis for making estimates of the size of a typical medieval burgher family. They are unsuitable for statistical analyses due to variations in the form of the will, the motivations for writing them, and the situation in which they were drafted. ${ }^{66}$ In many cases, children were not mentioned in wills because the parents were childless or made the will shortly after they married. In others, a will merely contained a bequest or only addressed the liabilities of the late husband toward his wife and debtors, i.e. it did not provide for the division of the estate among the testator's children and close relatives. In some cases, adult children were not mentioned in the will because they had already come of age and received their share of the estate. ${ }^{67}$ In many cases, if children were mentioned in the will, they were only enigmatically referred to by the Latin pluralis filii or liberi, or, the German, kinder. ${ }^{68}$

In wills in which the testator left instructions concerning the division of the estate among all his children, as he stated, in order to avoid family quarrels and feuds, the number of children mentioned is usually between two and four, and rarely five or more. Most studies on medieval urban populations corroborate such an estimate. ${ }^{69}$ Affluent burghers probably married more often and thus had more children than the average burgher family. ${ }^{70}$ These burghers often

66 Such calculations were made in some studies on wills, but they did not provide any new findings, and the authors themselves raised methodological doubts; e.g.: Brigitte Klosterberg, Zur Ehre Gottes und zum Wohl der Familie, 212-216; Paul Baur, Testament und Bürgerschaft, 205-220; Johannes Schildhauer, Hansestädtischer Alltag. Untersuchungen auf Grundlage der Stralsunder Bürgertestamente vom Anfang des 14. bis zum Ausgang des 16. Jahrhunderts, Weimar 1992, 100-113.

67 Sometimes, however, children who had already received their share of the inheritance were mentioned in wills.; cf. cons. 428, fol. 243 (1428); SCAB. 6, fol. 94 (1434); SCAB. 8, fol. 239-240 (1466).

68 It seems that at this time there was no custom or obligation to list all the descendants in the will under pain of its nullification, as Bartłomiej Groicki wrote in the mid-sixteenth century; cf. idem, Tytuty prawa majdeburskiego (Warszawa: Wydawnictwo Prawnicze, 1954), 182.

69 Andrzej Karpiński, Kobieta w mieście, 187; Stanisław Waszak, "Dzietność rodziny mieszczańskiej i ruch naturalny ludności miasta Poznania w końcu XVI i XVII w.," Roczniki Dziejów Spotecznych i Gospodarczych 16 (1954-1955), 365; Brigitte Klosterberg, Zur Ehre, 213-214.

70 For example, Margaret Pferdinne, the wealthy widow of goldsmith John Pferd, mentioned her brother's five children in her will: "Item so gebe ich den vonf kyndern meynes gebornen bruders von vatir und muttir Peter Pelczers das haws das ich Inne wone allin gleich eym als dem andern czu gleichim teile"; LT, fol. 52 (1458). Likewise, in her will from 1501, Margaret Czypserowa testified that she had two sons with her first husband, councillor Nicholas Zalcz, and six children with her second husband, Stanisław Czypser, "some of whom survived." At the time of writing her will, Margaret was married to her third husband, John Łowicz, with whom she also had children; cf. LT, fol. 165-166. 
even included stepchildren in their wills, which further complicated plans for the division of the estate. Children from a first marriage were seen as a threat to the widow (i.e. the second wife), and wills were often written to avoid disputes between these parties. Evidence from research also confirms that the number of children in the average Krakow family varied depending on its material situation, ${ }^{71}$ and whether the head of the family was an immigrant or a local burgher. ${ }^{72}$

According to Magdeburg Law, as it was applied in medieval Krakow, sons and daughters had equal rights to the property of their parents and inherited it in equal parts. ${ }^{73}$ This was a departure from traditional Polish land law, according to which daughters received a dowry in cash, while the sons or closest male relatives inherited the estate. ${ }^{74}$ The fact that daughters were permitted to inherit real estate property meant a part of the estate could come under the control of the daughter's husband, and thus de facto be lost as part of the family assets. Throughout the analysed period, a traditional division was nevertheless maintained in regard to movable property between what was to be inherited by sons or male relatives (hergewet, arma bellica) and by daughters or female relatives (gerade, paraphernalia). Children born from a second marriage also had the right to receive the same inheritance as children born from the first marriage, a fact that was often stated in wills. For example, in 1393, the affluent burgher Martin Junge decided that if he and his second wife had a child, it would receive the same inheritance as his son born out of his first marriage. ${ }^{75}$

71 "Researchers of family structures agree that the actual number of children depended on the financial situation of the parents"; Andrzej Karpiński, Kobieta w mieście, 187; Stanisław Waszak, Dzietność, 352-353; Brigitte Klosterberg, Zur Ehre Gottes und zum Wohl der Familie, 213-215.

One theory of historical demographics states that increased mortality and lower fertility rates among immigrants contributed to negative birth rates in medieval cities.; Jan de Vries, European Urbanization 1500-1800, Cambridge (Mass.): 1984, 185.

It seems that, apart from the regulations provided for in municipal law, Krakowhad its own book of judgements that contained principles providing for the equal inheritance of property regardless of the gender of the children: "omnes quinque liberi seu heredes dicti domini Nycolay Ruteni inter se diuident equalibus virilibus siue paribus porcionibus secundum ius et laudabilem consuetudinem ciuitatis Cracouie, prout est hactenus obseruatum"; NKiRMK, no. 103 (1330).

74 Statuty Kazimierza Wielkiego, ed. Otto Balzer, Ludwik Łysiak (Poznan: Nakł. Poznańskiego Tow. Przyjaciół Nauk, 1947), paragraph 131, 132; cf. Wacław Uruszczak, "Statuty Kazimierza Wielkiego jako źródło prawa polskiego," Studia z Dziejów Państwa i Prawa Polskiego, 3 (1999), 97-115; Ludwik Łysiak, Statuty Kazimierza Wielkiego w małopolskiej praktyce sądowej XV wieku," Studia Historyczne 19, no. 1 (1976), 25-39. em geborit"; cf. SCAB., no. 1816. 
However, Junge also stated that his stepson Stanisław (Stenczel) was to receive just three grivna. This was because Stanisław belonged to the family of his late father and was thus entitled to receive an inheritence from him. Junge, as his stepfather, was not obliged to share his property with Stanisław, and the bequest of three grivna was made merely to include him symbolically among the heirs. Stepsons, however, could inherit from their parents, thus giving rise to potential conflicts between stepparents and children from a second marriage. It can be assumed that the solution chosen by councillor Martin Chmiel in 1466 was a rather common one. In 1465 , Chmiel made a will in which he secured the dower of his second wife, Ursula, bequeathed his house to his son Jacob, and divided the rest of the estate among his other children. ${ }^{76}$ However, in 1466 , probably due to a family dispute, Chmiel persuaded his son Martin to testify before the court that he had already received the share of the family estate due to him after his mother or father's death. The son was made to swear that he thus had no further rights to his father's estate and would not question the choice of those acting as guardians for his stepmother and stepsiblings after Chmiel's death. ${ }^{77} \mathrm{~A}$ father's second marriage complicated the inheritance rights of children born of the first marriage. Disputes that arose with stepchildren could be risky for the second wife of the testator. The safest solution was to make a will and give children their due parts of the estate while the father was still alive. The situation of minor stepchildren dependent on their stepfather was more complicated. Before going on a pilgrimage in 1450, a Margaret made a mutual bequest to her husband Nicholas Pirich, ensuring that "after her death, he would guard and look after her children and his stepchildren until they came of age [ad annos pubertatis]." ${ }^{.78}$

However, relations between stepparents and stepchildren were not always problematic. Many different factors influenced the lives of Krakow burghers and, understandably, relations within families varied - it would be impossible to define a single model of family relations. Often, testators who did not have heirs of their own welcomed stepchildren into their family. In his 1435 will, Jost the Bowyer left his wife the house he owned in exchange for her dowry. With the consent of his brother Paul (who had greater rights to his inheritance), Jost also left his tools and workshop (werggeczew) to his stepson Hanczel. ${ }^{79}$ Another example is provided by the will of the affluent burgher Thob Johan, who bequeathed 400 florins to both his son John (Hanzel, Hensil) and his

\footnotetext{
76 SCAB. 8, fol. 204.

77 SCAB. 8, fol. 239-240.

78 sCAB. 7 , fol. 8 o.

79 SCAB. 6, fol. 108.
} 
stepson, a goldsmith, also named John (Hannus goltsmid), who also inherited his stepfather's market stall. Both the son and stepson were also given the right of presentation (ius praesentandi) to an altar erected by Thob Johan at St. Mary's Basilica. ${ }^{80}$ The affluent butcher Peter Crencz, in turn, wrote down that he conducted business with his stepson Matthias, and had an investment of 70 grivna in goods they had purchased together. ${ }^{81}$

Children came of age (anni discretionis) when they reached biological maturity, meaning they could have children of their own, and were thus ready to marry and start their own family. A system functioned during the Middle Ages that drew on ancient philosophy and medicine, in which human life was divided into seven-year stages, beginning with infancy (infantia), which lasted until the age of seven, followed by childhood (pueritia), which continued to the age of fourteen, puberty (pubertas), which ended when one reached the age of twenty-one, maturity (iuventus) and finally old age (senectus). ${ }^{82}$ Under Polish land law (as well as ecclesiastical law) boys came of age (anni discretionis) at 12,13, 14 or 15, depending on the region and the time at which the legal provision was introduced, while girls usually came of age at $12 .{ }^{83}$ In accordance with the Statutes of Casimir the Great, which regulated the law in Małopolska, both boys and girls were deemed to be of age when they turned $12 .{ }^{84} \operatorname{In} 1423$, Władisław Jagiełło stated in the Statute of Warta that boys came of age at 15 , while girls did so at $12 .{ }^{85}$ It was not until the early sixteenth century that statutes in the Krakow region began to state that children could assume control of their property when they turned $20 .{ }^{86}$

\footnotetext{
8 Lo, fol. 7-8.

$81 \quad$ LT, fol. 9o.

82 Dorota Żołądź-Strzelczyk, Dziecko w dawnej Polsce (Poznan: Wydawnictwo Poznańskie 2006), 16.

83 Małgorzata Delimata, Dziecko w Polsce średniowiecznej (Poznan: Wydawn. Poznańskie, 2004), 166-167.

84 "Similiter infantibus ad duodecim annos educatis, si tempore infanciae per quemvispiam iniuria fuerit illata violenciam agitare, pro qua agree non valebat propter defectum etatis, contra ipsos inpedientes seu iniuriantes"; Statuty Kazimierza Wielkiego, no. 74.

85 "[...] et quamvis eisdem super etate sit provisum, videlicet maribus ad quintumdecimum et femellis ad duodecimum annos inclusive, quod infra hoc tempus non teneantur respondere"; Statuta Terrestria in Conventionibus Cracoviensi et Wartensi laudata, ed. Bolesław Ulanowski, Krakow 1921 (Archiwum Komisji Prawniczej, 4), 457; Dorota ŻołądźStrzelczyk, Dziecko, 22; Małgorzata Delimata, Dziecko, 167.

86 "If someone who sells or pledges inheritable property to another dies, the sons of the deceased are to receive the inherited property. And if they are not of legal age, they should not be given it until they reach it. Thus, under common law the guardians should give
} 
According to the Sachsenspiegel, children became adults at the age of $12,{ }^{87}$ while under Magdeburg Law boys reached legal age at 14, and girls did so at 13.88 In accordance with the statutes of Krakow from 1342, boys could take control of their share of an inheritance at the age of 15 , while girls could do so once they were married (the husband then assumed this responsibility). ${ }^{89}$ In the Late Medieval period, the traditional boundary between childhood and maturity, which indicated the age at which one was considered sufficiently mature to undertake legal action, was set at 21 under municipal law. ${ }^{90}$ However, in the seventeenth century Polish land law began to consider 24 as the 'age of prudence' (anni puberum). ${ }^{91}$

It appears that Krakow's burghers considered a person 15 years of age, the point that marked the beginning of adulthood under Krakow's municipal statutes, to be too young and immature to become an heir. Since the late fourteenth century some testators had explicitly stated in their wills that their children would only assume control of their inherited property at a much later age. The councillor Nicholas Strelicz decided his wife was to give their son his share of the estate when the boy turned 20 . The daughter would be given

the property to the children when they are fifteen years old, and the children, having taken the inheritance, are to sue him; and yet according to the law, as is customary, the children shalt not sell or pledge the property until they are twenty years old, without the permission of well-benevolant relatives." Wybór źródet do historji ustroju i prawa sądowego Polski, vol. 2: Spisy prawa zwyczajowego koronnego, ed. Stanisław Kutrzeba, Adam Vetulani (Krakow: Gebethner i Wolff, 1930), no. 2 (1501 r.); cf. Małgorzata Delimata, Dziecko, 167,199 .

87 Jan Łaski, Commune Incliti Poloniae, Libri duo, part 1, 189.

88 Andrzej Karpiński, Kobieta w mieście, 22-23.

89 кDMK, vol. 1, no. 25; vol. 2, no. 26o, §1.

9o In John Łaski's codex, ambiguities stemming from the overlapping of different sources of law are apparent. In book one of Iuris Maydemburgensis such a note was made: "Quando puer est duodecim annorum, tunc potest eligere pro sua voluntate tutore. Et qui suus fuerit tutor, hic matri rationem facere habet et adolescent, quod cum bonis factum fuerit. Cum etiam puer fuerit duodecim annorum is mundiburdius, alias sui potens est factus, et potest in eo, iudicium perpetrari, et etiam bona sua a se sive tutore alienare. Sed innatam hereditatem, et proprium debet dare cum consensus heredum. Etiam iste puer de iure ad respondensionem valeat coartari seu compelli"; Jan Łaski, Commune Incliti Poloniae, Libri duo, part. 1, 189; in the part containing the articles of the Saxon Mirror it was established that: "Vir bonum potest eligere tutorem si necessitas fuerit, et carere potest si voluerit. Ultra viginti et unum annum vor ad annos pubertatis pervenit [...]. Quando adolescens ad annos pubertatis pervenerint extunc sue uxoris tutor esse potest"; ibidem, part 2, 208; cf. Urszula Sowina, Wdowy i sieroty, 25; Andrzej Karpiński, Kobieta w mieście, 22-23. 
her share of the estate when she married (of course only with the consent of her mother). ${ }^{92}$ Strelicz thus precisely defined the moment of his children's 'coming of age' (cum ad annos debite etatis). At the turn of the fourteenth and fifteenth centuries, six other influential testators stated that their sons would inherit, and thus have control over, their share of the estate when they turned $24 \cdot{ }^{93}$ It is not certain which legal system recognized the age of 24 to be the age of adulthood and prudence, but, surprisingly, such a specific age is only quoted in wills written from 1390 to 1400 . In later years, testators employed more generic terms. For example, the municipal notary Eustace uses the phrase 'when he reach his age' (wenne her czen seynen iaren kompt), ${ }^{94}$ while John Beme in 1465 wrote 'when he will reach a mature age' (ad matura pervenerit etatem). ${ }^{95}$

Such a significant raising of the age at which a child in Krakow was considered an adult was probably a reflection of the culture of the urban elite and their professional activity. In such an environment, maturity and independence were associated less with the ability to procreate and obey the wishes of one's elders, as traditionally had been the case, and more on one's knowledge, experience, level of literacy, and capacity to engage in legal acts.

Raising the age at which property could be inherited also affected when people married. Most first marriages were characterized by a considerable age difference - the man was usually at least several years older than the woman. Considering the high rate of maternal mortality, this difference had to be even greater in subsequent marriages. ${ }^{96} \mathrm{We}$ also need to bear in mind that while women who chose to remain widows for the rest of their lives were treated with respect (for remaining faithful to their late husband), men were usually expected to remarry, since only married men were granted the status of burgher, and thereby received city privileges. Both this fact and social expectations gave

92 “[...] si femella, quousque cum voluntate matris maritata fuerit"; SCAB., no. 1645. In 1395 Nicholas Dambraw specified that a daughter reaches legal age when she gives birth to children: "dy mait nicht e, is sey denne, das se fruchte habe"; sCAB., no. 2210.

93 SCAB., no. 1267 (1390), 1676 (1393), 2042 (1394), 2193 (1395), 2210 (1395); CONS. 427, fol. 149 (1400).

94 LT, fol. 61-63 (1459).

95 LT, fol. 86-87.

96 "The law, demographic relations and matrimonial policies often resulted in large differences in age between newlyweds and in situations where minors and the elderly were wedded."; Andrzej Karpiński, Kobieta w mieście, 172; Stanisław Waszak, Dzietność, 351-352, $365 ;$ cf. Krzysztof Mikulski, "Kondycja demograficzna rodziny mieszczańskiej w Toruniu w XVI-XVII wieku (na przykładzie rodziny Neisserów)," in Kobieta irodzina w średniowieczu i na progu czasów nowożytnych, ed. Zenon Hubert Nowak, Andrzej Radzimiński (Toruń: Uniwersytet Mikołaja Kopernika, 1998), 132-137. 
rise to a phenomenon that can be described as a 'rotation of marriages.' In the Middle Ages, men marrying two or three times was more the rule than the exception. Meanwhile, young women who married mature or older men often became widows at a relatively young age and later married younger partners. This was certainly true for young women from affluent burgher and patrician families, who achieved higher social status and increased their wealth through successive marriages to two or more rich burghers. For example, Margaret Czipserinne, a rich Krakow burgher woman who survived two husbands tried in her will to secure the future of her third husband, who was much younger and probably poorer than her. ${ }^{97}$

Once children (especially daughters) reached legal age, preparations began for them to start their own families: suitable candidates were selected, the betrothal was announced, and marriage followed. The first costs associated with moving children out of the house and into adulthood were connected with the wedding ceremony, though these expenses varied greatly depending on the social status of the family. For example, in her 1484 will, an olive oil merchant named Catherine divided her estate equally among her three children - two daughters, Catherine and Barbara, and a son, Bernard. She also stated that Bernard should be given an additional six grivna before the estate is divided, because Catherine and Barbara had already received expensive wedding clothes and accessories (nupciis necessaria). ${ }^{98}$ The affluent councillor Paul Ber also wished to divide his property in a fair manner. In 1467, all his children were given equal shares of the estate, except for his oldest daughter Barbara, the wife of John Schotcz, who received 200 grivna less. Ber stated that Barbara had been given clothes, belts, spoons and furniture when she married. As a father, Ber had also paid for the wedding. ${ }^{99}$ In the same fashion, in his 1469 will councillor Hippolyte Spilberger did not take into consideration the wedding expenses of his stepdaughter Margaret (Maruscha), because, as he stated, her husband Ulrich had worked with him, contributing to the family's wealth. ${ }^{100}$

$97 \quad$ LT, fol. $165^{-166 .}$

98 LT, 140-141.

99 "[...] meyne eldiste tochter Barbara Hannus Schotczynne czwehundert gulden mynner nemen sal denne der andern kindern eyns om des willen das ich sy nu ausgericht habe mit cleydern mit gorteln mit leffeln eciam mit alem hausgerethe und mit der hochczeit das foste geldes kostit"; SCAB. 8, fol. 270-271; cf. Krystyna Pieradzka, Pawet Ber, in PSB, vol. 1 (Krakow: Wrocław-Warszawa-Krakow: Polska Akademia Nauk, Polska Akademia Umiejętności, 1935), 444.

100 "Item seiner tochtir Maruscha, Ulrichs hausfrawen gibt her ouch gleich teyl, und dy ausrichtungis irer hochczeit sal ir nicht geacht noch abegeslagen werdin, dorumme das 
Wedding expenses included not only the costs of the wedding and reception, but also the costs of festive clothes and the things the bride-to-be was to receive in her dowry. For example, in his 1464 will, goldsmith Nicholas Brenner stated that he had manufactured expensive wedding accessories for Łazaria, the wife of Nicholas Slop, including a gilded belt, rings, a cross and a gilded and embroidered agnus dei. ${ }^{101}$

The scale and cost of wedding celebrations held by affluent burgher families in Krakow were comparable to those of the rich nobility in Małopolska. In the first version of his will from 1439, John Sweidniczer, one of the richest burghers in Krakow, left 800 grivna to each of his children. His two unmarried daughters were also given an additional 200 grivna for their wedding expenses $(c z u$ ausrichtunge er hochczeit). ${ }^{102}$ Some city statutes tried to regulate 'burgher weddings' and limit the extravagance and lavishness of these events. In order to ensure that burghers knew their rightful place in society, the municipal authorities imposed artificial and rigid restrictions on such things as the number of invited guests, meals and musicians. ${ }^{103}$ It seems, however, that wealthy Krakow burghers did not really obey these regulations. The wedding was a social and 'networking' event - one could strengthen the relationship between the families of the bride and the groom and provide for closer relations between the invited guests. A lavish wedding was a display of wealth, power and social status; for example, in 1543 a notary from Poznan wrote down a short epitaph in the municipal chronicle, praising the late physician John Wójcik. As the notary observed, John Wójcik was a renowned burgher, because "he was invited to every important wedding and ceremony in the city."104 One can imagine that for Krakow burghers the wedding was also an important social event, allowing them to entertain and rub shoulders with prominent figures.

During or immediately after the wedding the husband confirmed the amount of the dower (which had been set at the time of the betrothal). In his 1431 will, Matthias Polak, a tanner at the 'Jewish Gate,' stated that his wife Margaret should receive 20 grivna of her dower, adding that he had promised

Ulrich obengenant ir man getrewlich an ym gefarin hat, und getrewlich seine guttir ym hat helfin direrbtin"; LT, fol. 95 .

"Item so habe uch der frawen Lazarien Niclos Slopottynne of ire hochczeit und ouch der Thachter gemacht gortel of geslagen und forgolt und fingerleyn gemacht Creuczleyn und eyn Agnus dei vorgolt und heftleyn gemacht"; LT, fol. 83 . CONS. 428 , fol. 402 .

103 Najstarszy zbiór przywilejów i wilkierzy miasta Krakowa, vol. 2, ed. Stanisław Estreicher, Krakow 1936, no. 15 .

104 Kronika poznańskich pisarzy, ed. Jacek Wiesiołowski (Poznan: Wydawnictwo Miejskie, 2004), 51 . 
her this at their wedding. He also left her an additional 20 grivna as a dower in his will. ${ }^{105}$

Unlike in France or Southern Germany, testators in Krakow rarely appointed one of their sons as the primary heir to the entire estate. ${ }^{106}$ Merchants usually tried to divide their estate in equal parts among all their children. Only childless testators appointed a main beneficiary, usually one of their relatives, who would inherit their real estate property. A will made in 1462 by Jarosław Szarlej from his prison cell while awaiting execution, is interesting in this respect. ${ }^{107}$ This influential member of the Krakow city council had a number of children from two marriages. He refers in his will to four children from his second marriage, who were to receive 15 o florins each before the rest of the estate was divided in equal parts among all his children. Szarlej explained that these children were given preferential treatment because the children from his first marriage had already received shares of the estate when they started their own families. ${ }^{108}$ Szarlej's will is an interesting example because the testator made it in exceptional circumstances - while awaiting his execution. In it he displays particular favour for his youngest son, bequeathing him a cutlass decorated with silver and a gold ring "to remember him by."109 These special gifts ${ }^{110}$ appear to have signalled the symbolic appointment of a successor and heir to the family business. This seems even more probable in view of the fact that Szarlej's two other sons were probably destined for the priesthood. ${ }^{111}$ Interestingly, in his 1459 will the wealthy municipal notary Eustace pays particular attention to a signet ring (daumen ring) for the thumb, while listing in detail all the property his only son, also named Eustace, was

105 There is no mention of a bequest of the dowry at the time of the marriage of Matthias Polak and Margaret in bench court or council books. This may indicate both that a special book for dowry bequests, which could have been the first Krakowbook of wills, Liber testamentorum et Dotaliciorum, was lost, and that the marriage contract was merely a verbal agreement affirmed by witnesses, which was not subsequently certified before the municipal council; cf. CONs. 428 , fol. 29 o.

106 Brigitte Klosterberg, Zur Ehre Gottes und zum Wohl der Familie, 216-217.

107 Marcin Starzyński, Krakowska rada, 89-96.

108 "[...] iczunt dirczogin habe und ouch gehantlanget mit hulfe"; LT, fol. 73-74.

109 LT, fol. 74.

110 A number of such signet rings have survived to the present day, e.g. a ring with initials, probably belonging to a cloth merchant from Bristol, England was found in 2008 in the vicinity of that city; http://medievalnews.blogspot.com/2009/og/ring-belonging-to-15th -century-mayor-of.html (5 November 2019). The term thumb ring is sometimes still used for a signet ring; LT, fol. 61 .

111 "Item den andern czween sonen gebe ich meyne gutte cleider also wenne sy prister warden und dorczu man sal en lossen kelliche machen"; LT, fol. 74. 
to inherit. Thus, while Krakow merchants usually divided their estate in equal parts among all their children, they also often symbolically appointed one of their sons as the head of the family business.

The custom of designating one primary heir is even more apparent in the wills of Krakovian craftsmen, who made them to bequeath not only their movables and real estate, but also their workshop and the tools of their trade. If the testator had one or more sons, one generally inherited his tools, though they were sometimes divided evenly between two sons, as seen in the wills of the goldsmith Matthias Brenner ${ }^{112}$ and the blacksmith Martin Pasternak. ${ }^{113}$ However, if the testator was childless, his workshop was usually inherited by one of his closest relatives. The cooper Nicholas Blumental left alle werggeczew das czu dem hantwerg gehort to his nephew Matthias, ${ }^{114}$ the goldsmith John Polski left his workshop to his nephew Matysko, ${ }^{115}$ and the goldsmith Stanisław and goldsmith apprentice Johnny left their businesses to unnamed male relatives. ${ }^{116}$ If the testator decided that no relative was worthy of inheriting his workshop, he would sometimes leave it to a member of his wife's family. Nicholas Schobelga left his workshop to his son-in-law Michael;117 the archer Henczil left his to his brother-in-law; ${ }^{118}$ and the aforementioned Jost the Bowyer left his to his stepson. ${ }^{119}$ Some testators left their workshops to their wives and daughters, who were to continue running the family business. For example, the belt maker Nicholas Goldener left all his tools to his wife, ${ }^{120}$ as did Nicholas Baum, whose wife Barbara inherited allis werggeczew. Baum observed in his will that he and Barbara had worked together in his workshop (das czu unseren hantwerg dynet). ${ }^{121}$ The wills of other craftsmen also imply that wives often worked in workshops alongside their husbands. For example, in his $145^{8}$ will, shoemaker John Panzira left his workshop to his wife, allowing her to earn a living as a shoemaker (uti artem sutoriam). ${ }^{122}$ Similarly, in his 1458 will, shoemaker

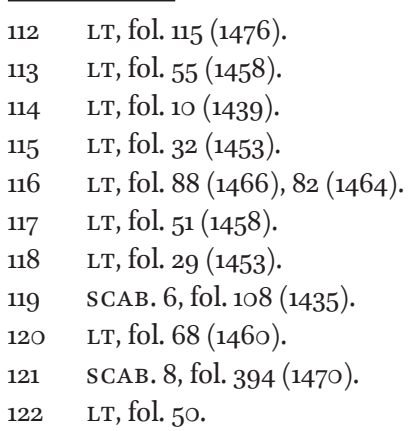


Nicholas Mewsil left his workshop and all his tools (schubang mit allen gerethe) to his daughter Justine. ${ }^{123}$

Some Krakow testators would discipline their defiant children by threatening to disinherit them. When John Michilwicz married his second wife Catherine in 1395, he explained in detail what part of the estate would be inherited by his daughter Margaret from his first marriage, and what part of the estate would be inherited by Catherine and the children born of his second marriage. In order to settle any potential legal issues and ensure the well-being of all his children, Michilwicz appointed four testamentary guardians (tutores). They were to look after the family, but they were also given the right to disinherit Michilwicz's disobedient children. ${ }^{124}$ In addition to numerous goods, councillor Franczko Neorze ${ }^{125}$ and the affluent pharmacist Paul Tanneman also gave their wives the right to disinherit disobedient children after their death. ${ }^{126}$ In practice, such instructions made the widows the family patriarchs. It was they who would decide the fate of their children, either single-handedly or with the help of the appointed testamentary guardians. For example, in her 1441 will, Dorothy Stelmecherinne stated that her daughter would be disinherited if she did not follow her instructions regarding the house. Her share of the estate would be given in equal parts to her brother (Dorothy's son) and in opera pietatis. ${ }^{127}$ However, the only Krakow testator known to disinherit his children and relatives was the affluent spice merchant Nicholas Barszcz. In 1449, he testified before the municipal council that he had earned everything through his own hard work (maximis laboribus aquisita) and thus decided to disinherit his vagabond (vagabunda) daughter and all his relatives. ${ }^{128}$

\footnotetext{
123 LT, fol. 54.

124 "[...] ap der eyns adir me desen nochseschreben vormunden nicht gehorsam wurde seyn, das dy selbin Vormunden irkenten, das meyn guth an em nicht bestat were, so sullen se volle macht haben deme vngehorsamen kinde seyn gut czu entwenden vnde das teil wenden an dy werk der barmherczigkeit noch willin der vormunden"; cf. SCAB., no. 2070.

125 "Item obir das allis, ap meyn son seyner muter nicht fulgen welde, adir welde ir wedirdris tun, so sal her gancz ausgeslossen seyn von alle meym gute czu ewigen tagen"; sCAB. 6, fol. 81 (1434).

126 "Item ap sich der kinder irkeyns wider dy vormunde adir wider dy muter seczen welde, dasselbe kind sal enperen seyns teilis czu ewigen tagen, und dy andern kinder mit der muter sullen desselben kindis teil nemen in dy gemeyne. Ouch gebe ich meyner hawsfrawen folle macht obir meyne kinder und obir allis gut, daz sy dobey tun und lossen mag, mit der vormunde rat und ane dy vormunde sal sy nichtis tuen"; SCAB. 6, fol. 113 (1435). 
Instructions regarding the division of the estate in the event of the death of one of the children also varied greatly. In his 1497 will, George Lange stated that he wanted to "avoid disputes between his wife and children,"129 and explained in detail who was to inherit the respective shares of the estate. Lange pointed out that in the event of the death of any of his children who were still minors, their share of the estate would be inherited by the child's mother (so irkeyn kint storbe so sal sulchs kindis teyl als recht ist komen an dy muttir). However, if she remarried, then the share of the estate belonging to the late child would be divided equally among her and the remaining children. We find similar dispositions in other wills. Indeed, under municipal law, in the event of the death of a minor, their share of the estate would be inherited by the mother. In turn, in the event of the death of the mother, her share of the estate would be inherited by her children alone. ${ }^{130}$ Since child mortality was high, the widow could in fact inherit a majority of the late husband's estate. We know that some husbands tried to avoid such a situation by formulating new inheritance rights in the event of the death of a child. For example, Nicholas Czeginkop, in his 1413 will, stated that in the event of the death of one of his children, their share of the estate would be divided in half. The wife would be given one share and the other half would be donated to opera pietatis. ${ }^{131}$ Some husbands included such provisions in separate contracts, as exemplified by an agreement made between the councillor Martin Chmiel, his second wife Ursula, and his son (also named Martin) from his first marriage (Ursula's stepson). The son agreed to honour his father's will, while Ursula agreed that in the event of the death of one of her children, their share of the estate would be divided equally between her, her children and her stepson Martin, even though she had the right to inherit the entire estate belonging to her late child. ${ }^{132}$ Some testators decided to divide the part of the estate which belonged to the late child into three parts. For example, Jacob Teudirneudir decided that it was to be divided in equal parts among his wife, his relatives and the Church. ${ }^{133}$ Similarly, in 1395, alderman John Dobschicz divided his estate among his relatives, a hospital and the members of the municipal council, who were to donate it to an opera pietatis of their choice. ${ }^{134}$ It is very probable that some testators were acting on the

129 "[...] das noch seinen tode czwischen seynir hawsfrawen und seynen kinder nichtis czwetracht irstunde"; LT, fol. 155 .

130 "[...] pars ipsius domine aut pueri defuncti ad ipsam dominam et ad reliquos pueros equaliter dividenda devolvatur"; SCAB., no. 1913 (1394).

131 SCAB. 4, fol. 104-105.

132 SCAB. 8, fol. 240 (1465).

133 That is, $1 / 3$ of the property is transferred to religious foundations to support the Church; cf. SCAB., no. 2042 (1394). 
advice of clergymen, who actively encouraged people to donate one-third of their estate to the Church. ${ }^{135}$

\section{$5 \quad$ Grandchildren}

Some testators also made bequests to the third generation - their grandchildren. In fact, grandchildren were sometimes treated more favourably than their parents, who had already received their share of the estate when they reached legal age and married. For example, Catherine, the widow of councillor Nicholas Plesner, left 100 grivna to the three sons of her daughter Kasia and 20 grivna to the son of her other daughter Anna, while her remaining money was bequeathed to opera pietatis. ${ }^{136}$ Similarly, mine administrator and councillor Gotfrid Fattinante of Genoa left some parts of his estate to his grandson; other family members did not inherit anything. ${ }^{137}$ In 1488, Margaret Szolwiczinne made a bequest to her only daughter, but she also left one of her houses in the city to her three grandchildren, because she wished to secure their future. ${ }^{138}$ While grandchildren also ensured that the family line would be continued and that testators would be remembered, as minors they were also vulnerable and required special care. While bequests made to one's grandchildren were essentially made to one's children, most wills clearly stated that the grandchildren's property could only be sold or used as security for a loan once the grandchildren reached legal age.

Siblings, Nieces and Nephews

In most wills, relatives who were not members of the immediate family played a secondary role. ${ }^{139}$ Many of them were referred to not by their name but only briefly and generally as 'relatives' (consanguinei) who were disinherited by means of a testamentary disposition. ${ }^{140}$ Nevertheless, the testator's siblings and their children, and sometimes even 'cousins,' were quite often named as

\footnotetext{
135 See Chapter 1, Section 2, p. 36.

136 SCAB., no. 1755 .

137 He donated the rest for pious deeds and to his servants and associates; cf. KDWac., vol. 2, no. 396, 182-185 (1393); Józef Garbacik, Gotfrid Fattinante, in PSB, vol. 6 (Krakow: Polska Akademia Nauk, Polska Akademia Umiejętności, 1948), 377-378.

$138 \quad$ LT, fol. 145 .

139 Brigitte Klosterberg, Zur Ehre Gottes und zum Wohl der Familie, 226.

140 E.g. SCAB., no. 1816 (1393); SCAB. 5, fol. 158a (1428); SCAB. 6, fol. 55 (1433); CONS. 428, fol. 513 (1448); LT, fol. 146 (1488).
} 
beneficiaries; in fact, testators made willingly the bequests to their nephews and nieces. This was especially true of childless testators, for whom nephews and nieces served in their wills as 'substitute' heirs. In 1393, Stanisław Mochaw left his entire estate to his nephew Hannos vom Salcze. He designated him as his primary heir, and at the same time disinherited all his other relatives. ${ }^{141}$ Some childless testators left different sums of money to their various siblings, nieces and nephews. ${ }^{142}$ For example, in 1450 , the childless coat maker (mentler) Nicholas made bequests to his wife (who received her dower) and for opera pietatis. He also made bequests to his niece Katrzyna (who lived with him and his wife) and his nephew (who lived in a monastery in Tyniec). The majority of his estate, however, was left to his siblings, John Walter from Łańcut (Lanczhuth), Margaret from Pilzno and Dorothy from Biecz. ${ }^{143}$ Siblings were also often treated as 'substitute' heirs. For example, in his 1475 will, the goldsmith (goltsmid) Nicholas left ten florins to each of his two brothers and his nephew (who lived with him), but only in the event of the death of his own children. ${ }^{144}$ In some cases, more affluent testators helped the children of their poorer siblings by allowing them to live with them and teaching them their trade. As the above examples demonstrate, some childless testators ultimately decided that their siblings, nieces, or nephews should inherit their workshops or market stalls.

\section{7}

\section{Other Relatives}

Other relatives were rarely named in wills - they usually constituted a threat to a childless testator or his spouse, because they had the right to a share of the estate and to question bequests made by a childless testator. For this reason, Margaret Prewszinne testified before the municipal council that she had obtained all her property through her own hard work or from her husband, as a dower, and had not inherited anything from her relatives. ${ }^{145}$ Similarly, in 1491, Barbara, daughter of the late Michael Unger, testified that she had no

\footnotetext{
141 SCAB., no. 1654.

142 SCAB., no. 1676, 1693, 1816, 2093, 2210.

143 SCAB. 7 , fol. 81.

144 SCAB. 8, fol. 579 .

145 “[...] gutter dy yr got gegeben hat, und nicht von yren frunden anyrstem met noch angekomen, sundir swerlichen dyarbeytet hat und von yrem elichen manne gemorgengobet synt"; LT, fol. 88 (1466).
} 
living relatives who could share in the estate, and thus made Christ her only heir. ${ }^{146}$ Most testators used a ready-made formula to disinherit relatives who were not explicitly named in the will. In Latin it read omnibus aliis amicis suis et consanguineis omni exclusis a percipcionem dictorum bonorum suorum, ${ }^{147}$ and in German of das testament slisse ich aws alle meyne frunde und nesten. ${ }^{148}$ However, not all testators disinherited relatives who were not next-of-kin, leaving them shares of the estate either to avoid disputes or to honour the family bond. Thanks to the institution of the will, the testator was free to dispose of his estate as he wished. Jacob Teudirneudir and John Dobschicz both decided that in the event of the death of their children, their relatives were to inherit one-third of their estate. ${ }^{149}$ Stanisław Mochaw left his relatives no real estate, but he recognized their rights to the traditional hergewet. ${ }^{150}$ In 1461, Simon, a needle maker (noldener), made a bequest of 20 florins to his relatives "who will come within a year and a day and are indeed next-of-kin."151 If no relatives came forward, the money was to be donated to St. Mary's Basilica in Krakow. Similarly, in his 1466 will, butcher Peter Krencz left his clothes, personal belongings and armour to his appointed testamentary guardians. They were to either give them to his relatives or, should no relatives come forward, donate them to opera pietatis. ${ }^{152}$ Since relatives had the right to the testator's personal belongings (the hergewet) and real estate (if there were no documents certifying its purchase), they sometimes engaged in long-running disputes with the widow. Most testators thus tried to protect their widows by granting them the right to continue living in the family house. ${ }^{153}$ Municipal books occasionally inform us that the executors of the will were allowed to act independently, i.e. they did not have to follow the will to the letter. For example, two members of the city council, John Kletner and Jacob Wilkowski, the executors of Dorothy Sweszniczka's will, helped her relative, the shoemaker Bieniak from Wolbrom (de Wolfram), even though he was not mentioned in the will. They

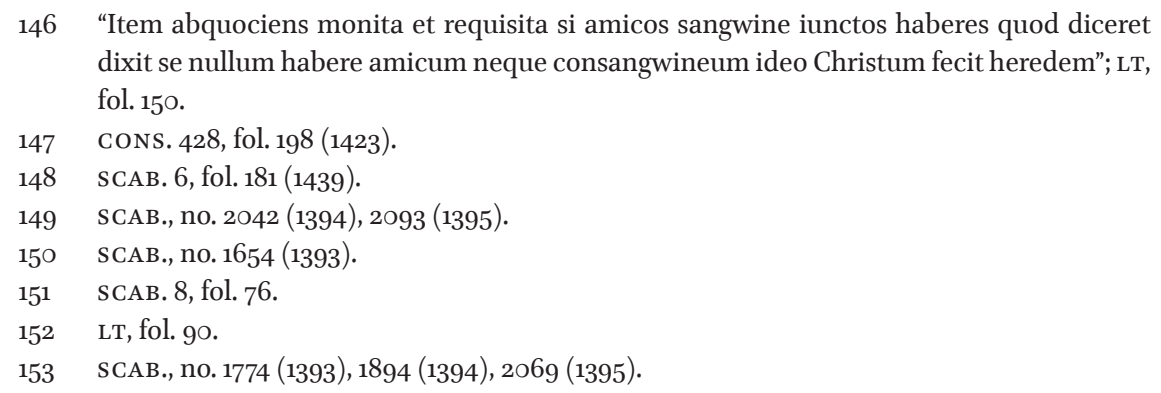


did so "because he was poor. The man was kindly given three grivna and gave his assurance he would not ask for anything else."154

\section{$8 \quad$ Servants and Co-workers}

People who lived under the same roof or worked together day-to day in the same workshop or market stall understandably developed strong attachments based on a sense of loyalty and mutual affection. Male and female testators often made bequests to their female servants, male servants, cooks, notaries, teachers and physicians. The amounts and types of goods bequeathed varied. Some testators were more affluent than others, but the emotional bonds that grew between them and their servants differed, depending in part on the latter's tenure and the nature of their work. Only rich burghers could afford to employ numerous servants on a daily basis, or to make bequests to their servants, often at the expense of their closest relatives. Such bequests are first seen in the wills of the Krakow mine administrator Paszko in 1358, councillor Gotfrid Fattinante of Genoa in 1393, and Dorothy Banarika, widow of the alderman and stall-holder Martin, in 1394. It is most likely that none of them had children; thus, they rewarded their servants, who were not their blood relatives. Paszko left 50 grivna to his servant Nicholas, which constituted one third of all the money he bequeathed. ${ }^{155}$ In the second of her three surviving wills, Dorothy Banarika gave her two servants, Catherine and Anna, respectively four and two grivna. ${ }^{156}$ The third testator, Gotfrid Fattinante of Genoa, demonstrated the keenest interest in his workers. He named his chaplain and notary (in Latin capellano et notario suo) Peter prebendary of the altar he established at St. Mary's Basilica. Meanwhile, his physician John was made prebendary of the other altar at All Saints Church (domino lohanni presbytero domus sue et medico assignauit). A separate bequest was made to his servant and household member Niklos, who inherited all of Fattinante's household movables,

154 "Item Byenak de Wolfram sutor qui se dicit et dixit amicum et propinqum prefate Dorothee non ex alicuis Iuris debito sed ex mera gratia et benivolencia dominorum intuita pauperitate eis receptis a nobis tribus marcis de prefato testamento recognovit, se iam amplius nullus habere ad illud abernunciat que eidem proximitati, et omni iuri quod habere posset in ewum"; LT, 120-121 (1476).

155 NKiRMK, no. 1693 .

156 This bequest was one of many pious bequests made to the Church and the poor; $\mathrm{cf}$ sCAB., no. 1893 . 
including clothes, furs, coats, tables, chests, sheets and the like. ${ }^{157}$ Given how rich Fattinante was, this must have been a very generous bequest. Other servants and workers also received gifts. Rudillon Reger and Nicholas Rothe, who had lost their eyesight working as miners in one of Fattinante's mines, were given 100 grivna. Four of Fattinante's servant-miners injured in the mine in Bochnia were sent to a hospital in this town. The remaining members of his household were given 100 grivna (they were to divide the money among themselves). ${ }^{158}$

Fifteenth-century testators sometimes emphasized that the servants to whom they had made bequests had worked for them for many years, which in practice meant that they were treated like family members. For example, in her 1493 will, Helena, wife of Nicholas Hefter, left her black coat and dress to her servant, Catherine, because she had served her faithfully for many years. ${ }^{159}$ Similarly, the municipal notary John Stolle ordered that after his death, in addition to an inheritance of 10 grivna, his faithful servant Margaret was to be given a good new coat. ${ }^{160}$ In 1410, Anna, widow of Nicolas Bothener, made a generous bequest of ten grivna as an annuity to her long-time "servant and notary" (Irem dyner und camirschreiber) Nicholas Jenyla. ${ }^{161}$

Servants were sometimes more akin to co-workers and factors, and therefore held in very high regard. For example, Burghard, a servant of John Sweidniczer, was referred to in Sweidniczer's will as servant (dyner), while in fact he was his master's 'right hand,' buying and selling lead, ${ }^{162}$ copper, and cloth worth hundreds of florins in Košice and Levoca. In addition, Burghard was named as an executor of Sweidniczer's will and a guardian of his children, for which, as well as for his faithful service, he received 200 florins. ${ }^{163}$ This was a very gener-

157 "Preterea res omnes suas videlicet vestes, pelles, pellicia, togas, mensas, cistas, lectisternia ac omnia vniuersaliter et singula, quibuscumque vocitentur nominibus, nullis penitus exceptis, in predicta domo, quam inhabitat, existentes ac existencia, Nicloso cubiculario suo et familiari de presenti earundem cedens possessionem et in ipsum Niclonem transferens, cum omnimoda faciendi et dimittendi facultate legauit"; KDWac., vol. 2, no. 396, $182-185$ (1393).

$15^{8}$ "[...] et tercium centum marcas prouidis Rudgloni Reger et Nicolao Rothe lumine oculorum in suo seruicio proch dolor orbato, familiaribus suis diuturnis, quartum centum marcarum inter ceteram suam domus sue familiam secundum maius et minus distribuendum contulit atque dedit"; ibidem.

"Item yren swarczen mantil und yre kursnen hat sy befolen zu geben Katherine yrer dynerynne wen sy hat ir getrewlich file ior gedynet"; LT, fol. 153 .

16o CONS. 429, fol. 27-28.

161 CONS. 427, fol. 365-366.

162 Danuta Molenda, Polski otów na rynkach Europy Środkowej, 104-106.

163 LT, fol. 39-45 (1457). 
ous bequest considering that Sweidniczer's two other servants, the notary Paul and teacher Kacper, were given only three and four grivna respectively. Two members of the city council, John Pitczen and John Kletner, also made generous bequests to their servants. In 1457, John Pitczen left his notary (named as 'my bachelor,' in Latin meinem baccalario) John his valuable clothes (a gown lined with marten fur, a black coat, and a black dress lined with fur) and, additionally, four grivna for his faithful service. In 146o, John Kletner, in turn, gave his servant (meynem dyner) John Newmargten 300 florins "in outstanding payment" (vor seyn vordint lon). The servant additionally received 300 florins for his faithful service (getreulich gedinet und gehantlagent hot) and was forgiven a debt of 83 florins. ${ }^{164}$ John Kletner also left 100 florins to his servant (meynem knechte) Staszek as payment and remuneration for his faithful service during Kletner's illness.

In exceptional cases, servants were named by the testator as the main heir. For example, in one version of the will of the municipal notary John Stolle, his housekeeper (schafferinne) was given a house at Hospital Street (she could stay in it as long as she lived) and all his movables, including sheets, books and other household items. ${ }^{165}$ Similarly, in 1450 , before going on a pilgrimage, Dorothy Specfleischinne bequeathed her real estate property, movables and paraphernalia to her former servant Stanisław, a painter (pictor). ${ }^{166}$

The trust some testators placed in their servants was in some cases apparently reciprocated. This is seen, for example, in a 1439 bequest by John, a longtime servant (famulus senex) of Anna Willuschinne, who asked her to donate the wages he was due to the opera pietatis of her choice, because she most likely knew better than he how the money could be put to good use. ${ }^{167}$

Some bequests made to servants may have represented wages due to them, especially when the bequeathed sums were no higher than a few grivna. ${ }^{168}$ In most cases, however, such bequests were a testament to a paternalistic relation to the servant that differed from other employer-employee relations. Those employing servants were not only supposed to give them orders, but also to take care of 'their people.' This is most evident in the practice of bequeathing to servants new or used items of clothing. Such gifts were material and practical,

\footnotetext{
164 LT, fol. 67.

165 SCAB. 6, fol. 186 (1439).

166 SCAB. 7 , fol. 89 .

167 SCAB. 6, fol. 19 o.

168 This is suggested by, among other things, the execution of the will of Szymek from Jewish Street. The son of the deceased paid five grivna to a Barbara's maid, despite the fact that such a provision was not included in the will; SCAB. 8, fol. 213 (1465).
} 
but also thoughtful, reminding the servant that their former employer was looking after them. For example, Margaret, widow of the miller Sigismund, left her servant Claire two dresses, two coats and two bed sheets. ${ }^{169}$ In 1464 , Łazaria, the wife of Nicholas Slop, left her servants Catherine and Barbara one dress and one coat each. ${ }^{170}$ In 1436, councillor Wilhelm Willand bequeathed to his servant Matthias 24 grivna and his old clothes. ${ }^{111}$ Bequests made to servants were often considered charity donations or opera pietatis. At the same time, they also demonstrated that employers cared and felt responsible for their faithful servants and other workers, who very often had lived in their house for years. Some childless testators considered their servants members of the family. This may have been true for Gotfrid Fattinante of Genoa, John Stolle and Dorothy Specfleischinne. Likewise, testators who had children also often treated their servants and workers as valuable additions to their businesses or workshops, or simply as members of the household who took care of the home, worked in the kitchen, and raised the children.

Occasionally, some testators included in their wills people who were neither their relatives nor servants; in such cases, however, they clearly stated that these people were important for them. Many of these beneficiaries were lay people, but it is difficult to determine the exact nature of the relationship between them and the testators. Perhaps some of them belonged to the testator's extended family, while others could have been neighbours or friends from a guild, fraternity or tavern.

\section{$9 \quad$ The Image of the Burgher Family as Presented in Late-Medieval Wills}

The wills shed light on many of the family relations in 14-15th c. Krakow. Undoubtedly, wills were 'tools' that were deliberately used to actively shape these relations by changing the traditional rules of inheriting property, including and excluding chosen relatives and friends from heirs, and planning the future of the loved ones. The sum of these individual practices conditioned by

\footnotetext{
169 "Item czwene recke eynen vom bloen gewande den andirn von harris und czwene mentil eynen von harris der andir eyn regen mantil unde czwe par leylach bescheide ich Clare meyner dynerynne"; LT, fol. 79 (1463).

170 "Item gab Katherine irr dinstmayt iren bloen rokund iren swarczen harris mantil [...] Barbare der andern mugen dinstmayt gebit sy iren newenfarben harris rok und eyn alden swarczen mantil den sy iczund hat"; LT, fol. 87 .

“[...] jopen, hozen swarczen rok der mit fuchsen gefutirt ist”; cons. 428, fol. 369 .
} 
very specific relations within different bourgeois families reveals some general trends in the late medieval transformation of this basic social unit. Therefore, wills demonstrate that the institution of family is a changeable concept depending not only on cultural scripts but also on the living conditions, life needs and social position of individuals.

The majority of bequests either took the form of mutual donations or terse instructions meant to secure the well-being of the testator's spouse and children. ${ }^{172}$ However, some testators also named in their wills numerous siblings, cousins, grandchildren, business partners, writers, servants and cooks. Even if we take into account the fact that wills were for the most part highly standardized official documents, we can see that they document the existence of two different family models in late-medieval Krakow. On the one hand, we have a classic urban phenomenon, namely the craftsman's small nuclear family. On the other hand, we have evidence of the emergence during this period among members of the patriciate of the model of a large or extended family, which also included servants. As mentioned above, quantitative research does not provide an accurate picture of how popular these two models were due to the limited number and nature of available sources. However, the analysed wills demonstrate that affluent burghers usually developed more complex family relations than moderately rich representatives of the urban municipality. For example, in his 1465 will, councillor John Beme made bequests not only to the Church and the poor, but also to, among others, his wife Ursula, sister Miotka, sister Agnes, nephew Peter from Gdańsk, the poor relatives of his wife Ursula, master John and his sister Margaret, the goldsmith (aurifabrisse) Catherine, his nephew Nicholas, his servant's daughter Anna, another servant called Anna, the cook Margaret, the grandchildren born in the marriage between his daughter Anna and Stanisław Graser, and his grandchildren born in the marriage between his daughter Ursula and the future councillor John Turzon. ${ }^{173}$ Such a large extended family was not an exception among the richest members of the Krakow patriciate. Councillors John Sweidniczer (in 1452), ${ }^{174}$ Konrad Lang (in 1462), ${ }^{175}$ and John Czenmark (in 1436 ) ${ }^{176}$ also made bequests to their relatives, in-laws, and friends. It seems that the differences between an affluent patrician family and other members of the urban municipality had to do with social status, the nature of their employment, family history and lifestyle. The extended burgher family was a means for acquiring social and financial

\footnotetext{
172 See introduction, section 1, p. 6.

173 LT, fol. 86-87.

174 LT, fol. 39-45.

175 LT, fol. 72.

176 CONS. 428 , fol. 354 .
} 
prominence. Arranged marriages to the daughters and widows of members of the patriciate allowed men to climb the social ladder. Large trading companies were usually family owned and operated - members of Krakow's merchant families therefore tended to live and work in major urban trading hubs somewhere in the vicinity of Krakow, thereby creating branches or trading posts for the family business. ${ }^{177}$ Many burghers saw their relatives as 'social capital' that would help them accumulate economic capital.

However, Krakovian artisans and small traders (often first-generation or second-generation immigrants) thought in different terms. Since their personal commitment and skills determined their success, they cared mainly about their nuclear family, about the well-being of their children and spouse, and saw their distant relatives, who often lived in other towns, as a threat. Most wills and 'bequests made in the event of death' demonstrate that testators tried first and foremost to secure the future of their nuclear family, i.e. their spouse, children, and sometimes siblings. In any case, the very concept of the family no longer adhered to the somewhat archaic provisions of municipal law based on the Sachsenspiegel or Magdeburg Law. In the late-medieval city, the burgher family was usually a nuclear family - the strongest family bonds existed between the spouses, children and sometimes siblings. Distant relatives were considered a threat to the well-being of the testator's nuclear family because they were entitled to receive inheritance by default, which often provided the motivation for the testator to make a will in the first place, in order to protect their nuclear family. In both the cases of the artisans and the burghers, however, and depending on individual needs, testators made wills in order to control and protect their estate, and thus their families.

Wills both exemplified and brought about changes in the bonds that existed between members of the late-medieval burgher family. As has been demonstrated, in the late Middle Ages, social bonds, which were often contractual but ultimately derived their strength from the emotional commitment of the parties involved, became more important than kinship. ${ }^{178}$ With the support and blessing of the Church, the institution of marriage was also considerably strengthened. Living under the same roof created strong relationships between people - the ancient concept of the familia, which included workers, servants and other members of the same household, was reformulated in keeping with that notion.

\footnotetext{
177 For example, the younger brother of Krakow councillor John Sweidniczer moved to Toruń, where Sweidniczer already owned real estate and maintained business relations. John's older son Jorge also moved there; cf. LT, fol. 39-45.

178 Jack Goody, The Development, 132.
} 